\title{
CONSERVATION OF THE GENERIC NAME BORRELINA AND DESIGNATION OF THE TYPE SPECIES
}

Request for an Opinion. File No. 53.

by Kenneth M. Hughes

University of California

In 1953, Bergold proposed the name Bolle a to replace the name $B$ or relin a Paillot for that genus of rod-shaped insect viruses occurring in polyhedral inclusions. Bergold considered the description on which the name Borrelina bombycis Paillot 1926 was based to be inadequate and states that since this, in his opinion, is true, "there was no justification for Holmes to choose Borrelina violating the rule of priority. Therefore, in order to overcome the general confusion, the name Borrelina is rejected and an entirely new name now proposed." In so doing, Bergold has retained the type specific epithet, bombycis, though rejecting the generic name, Borrelina. It is not clear whether this action by Bergold is justified or in accord with generally accepted taxonomic procedures.

A number of names have been applied to the causative agent of silkworm polyhedrosis in the past. Most of the authors applying such names, however, did so under the impression that they were naming some type of microorganism other than a virus. Thus we find in the literature such names as Micrococcus lardaris Krassilstschik 1896, Microsporidium polyedricum Bolle 1894, Entomococ cus bombycinus del Guercio 1929, and others similarly inappropriate to a virus. Paillot, alone, applied a name to this entity with the full realization that he was dealing with a virus. It is true that Paillot's description could beconsidered inadequate, as judged by present knowledge of these viruses, but there is no question as to the identity of the virus to which his name was applied.

When Holmes sought to classify the viruses he accepted and used the name proposed by Paillot (changing the spelling of the generic name from $B$ or rellina to $B$ orrelina to correct what he interpreted as an error in spelling). Holmes' 
description was no more adequate than that of Paillot.

Recognizing what he later (Steinhaus, 1953) termed "certain errors, weaknesses, and inadequacies in the Holmes treatment of the insect viruses," Steinhaus (1949) published a revision of the insect virus portion of Holmes' work. In it, the genus Borrelina Paillot, and the species $B$. bom bycis Paillot were retained. Genus and species were characterized much more fully than had been done previous ly. With this work, the nomenclature would seem to be firmly fixed in the literature for Paillot had first named the virus, Holmes had incorporated it in his very inclusive systematic scheme, and Steinhaus had associated an adequate description with the name.

The whole subject was reopened, however, when Bergold's 1953 paper appeared, seemingly contributing to the confusion by proposing a new name, Bollea, to replace Borrelina. Bergold's objections to the name Borrelina seem to be the following:

1). "The fact that the original description of the genus Borrelina given by Paillot (1926) was such that it could be applied to the agents of three different diseases, invalidates the description for any one of them." (Bergold 1953, p. 496). Paillot placed in the genus Borrelina the agent of silkworm polyhedrosis ( $B$. bomb viruses which Steinhaus later removed and placed in two new genera. Rather than there being anything unusual in this, it appears to the writer that such a procedure is of common occurrence and is accepted practice in the systematic revision of any group of organisms.

2). "...the description of Borrelina bombycis is not adequate." (Bergold 1953, p. 496). Perhaps it is quite true that, from the standpoint of modern knowledge, Paillot's description was inadequate, but it seems questionable how much unanimity might be found among present-day virologists as to what constitutes an "adequate" description of a virus. It might be noted that in some fields of systematics nothing more than a published photograph of the organism with name associated is considered an adequate description 
if it identifies the organism sufficiently. This objection of Bergold's appears to be answered by the fact that Steinhaus linked the name to a more complete description. It is doubtful if Bergold would question the adequacy of Steinhaus' description inasmuch as the latter composed his description almost entirely from data published by Bergold. The fact that Bergold rejects the generic name Borrelina but accepts its specific epithet bombycis would seem to indicate that Bergold does not find previous descriptions entirely inadequate.

3). Bergold does not consider Paillot's work acceptable since he does not believe that Paillot "saw" the virus. This belief may be valid but it is one in which not all other workers share. The writer's investigations on insect viruses (e.g. Hughes 1950) have led him to the belief that it is quite probable that Paillot did see the silkworm virus. This question, however, is one that can never be resolved beyond doubt and one that seems to be of questionable importance. The important points appear to be that Paillot, having determined that he was working with a filterable virus, applied a name to that virus, and that his description was adequate enough to insure that the identity of the virus has not been lost or confused.

4). "...there was no justification for Holmes to choose Borrelina violating the rule of priority." (Bergold 1953, p.497). At least five names were proposed for the agent of the silkworm disease prior to the time that Paillot proposed his. As pointed out earlier, the authors of these names believed that they were naming a microorganism of some kind other than a virus. Thus the names are all such as to be rather inappropriate for a virus. Bergold does not propose that Borrelina be rejected in favor of one of the previous ly-proposed names, but, rather, appears to the writer to be himself violating the rule of priority in proposing an entirely new one.

Bergold justifies his naming of the genus for Bolle by citing that worker's contributions to present knowledge of the silkworm virus. The writer does not intend to deprecate the work of Bolle. Whether or not he made a greater contribu- 
tion than Paillot is beside the point. The important facts are that both men proposed names for the agent of silkworm polyhedrosis. Bolle, believing that he was working with a protozoan, proposed the name $\mathrm{Microsporidium} \mathrm{polye} \mathrm{-}$ dricum. Paillot, recognizing the agent to be a virus, proposed the name Borreliina bombycis. Bolle's name, though preceding Paillot's, hardly seems applicable to a virus. Bergold does not suggest using the name proposed by Bolle, but creates a new one honoring Bolle.

Unless there are specific rules which would invalidate the name Borrelina it would appear that substitution of the name Bolle a would be in violation of Principle 9 of the Code. Furthermore, Principle 1 which deals with fixity of names and the "avoidance of all useless creation of names" would seem to be applicable.

\section{REFERENCES}

Bergold, G. H. 1953. On the nomenclature and classification of insect viruses. Ann. N. Y. Acad. Sci., 56:495-516.

Bolle, J. 1894. Il giallume del baco da seta. Notizia preliminare. Atti e Mem. dell' I. R.Soc. Agr. Gorizia, 33: 193.

Holmes, F.O. 1948. Order Virales, the Filterable Viruses. Bergey's Manual of Determinative Bacteriology. pp. 1225-1228. 6th ed. R.S. Breed, E. G. D. Murray, and A. P. Hitchens

Hughes, K. M. 1950. A demonstration of the nature of polyhedra using alkaline solutions. J. Bact. 59:189-195.

Paillot, A. 1926. Sur une nouvelle maladie du noyau ou grasserie des chenilles de Pieris brassicae et un nouveau groupe de microorganismes parasites. Compt. Rend. Acad. Sci. Paris, 182:180-182.

Steinhaus, E. A. 1949. Nomenclature and classification of insect viruses. Bact. Revs., 13:203-223.

Steinhaus, E. A. 1953. Taxonomy of insect viruses. Ann. N. Y. Acad. Sci. 56(art. 3):517-537. 